\title{
Ulnar hypoplasia-split foot syndrome
}

INSERM

\section{Source}

INSERM. (1999). Orphanet: an online rare disease and orphan drug data base. Ulnar hypoplasia-split foot syndrome. ORPHA:1122

Ulnar hypoplasia-split foot syndrome is characterised by the association of severe ulnar hypoplasia, absence of fingers two to five, and split-foot. It has been described in four males belong ing to two generations of the same family. X-linked recessive inheritance is suggested, but autosomal dominant transmission cannot be excluded. 